\title{
Satellite tagging highlights the importance of productive Mozambican coastal waters to the ecology and conservation of whale sharks
}

\author{
Christoph A Rohner ${ }^{\text {Corresp., }}{ }^{1}$, Anthony J Richardson ${ }^{2,3}$ ， Fabrice R A Jaine ${ }^{1,4,5}$ ， Michael B Bennett ${ }^{6}$, Scarla J \\ Weeks $^{7}$ ， Geremy Cliff ${ }^{8,9}$ ， David P Robinson ${ }^{10}$ ， Katie E Reeve-Arnold ${ }^{11}$, Simon J Pierce ${ }^{1}$ \\ 1 Manta Ray \& Whale Shark Research Centre, Marine Megafauna Foundation, Praia do Tofo, Mozambique \\ 2 CSIRO Marine and Atmospheric Research, Dutton Park, QLD, Australia \\ ${ }^{3}$ Centre for Applications in Natural Resource Mathematics (CARM), School of Mathematics and Physics, The University of Queensland, St Lucia, QLD, \\ Australia \\ 4 Sydney Institute of Marine Science, Mosman, NSW, Australia \\ 5 Department of Biological Sciences, Macquarie University, North Ryde, NSW, Australia \\ 6 School of Biomedical Sciences, The University of Queensland, St Lucia, QLD, Australia \\ 7 Biophysical Oceanography Group, School of Geography, Planning and Environmental Management, The University of Queensland, St Lucia, QLD, \\ Australia \\ 8 Kwa-Zulu Natal Sharks Board, Umhlanga, KZN, South Africa \\ 9 Biomedical Resource Unit, University of KwaZulu-Natal, Durban, KZN, South Africa \\ 10 Shark Watch Arabia, Dubai, United Arab Emirates \\ 11 All Out Africa Marine Research Centre, Praia do Tofo, Inhambane, Mozambique \\ Corresponding Author: Christoph A Rohner \\ Email address: chris@marinemegafauna.org
}

The whale shark Rhincodon typus is an endangered, highly migratory species with a wide, albeit patchy, distribution through tropical oceans. Ten aerial survey flights along the southern Mozambican coast, conducted between 2004-2008, documented a relatively high density of whale sharks along a $\sim 200 \mathrm{~km}$ stretch of the Inhambane Province, with a pronounced hotspot adjacent to Praia do Tofo. To examine the residency and movement of whale sharks in coastal areas around Praia do Tofo, where they may be more susceptible to gill net entanglement, we tagged 15 juveniles with SPOT5 satellite tags and tracked them for 2-88 days (mean $=27$ days) as they dispersed from this area. Sharks travelled between 10 and 2,737 km (mean $=738 \mathrm{~km}$ ) at a mean horizontal speed of $28 \pm 17.1 \mathrm{SD}$ $\mathrm{km}$ day $^{-1}$. While several individuals left shelf waters and travelled across international boundaries, most sharks stayed in Mozambican coastal waters over the tracking period. We tested for whale shark habitat preferences, using sea surface temperature, chlorophyll-a concentration and water depth as variables, by computing 100 random model tracks for each real shark based on their empirical movement characteristics. Whale sharks spent significantly more time in cooler, shallower water with higher chlorophyll-a concentrations than model sharks, suggesting that feeding in productive coastal waters is an important driver of their movements. To investigate what this coastal habitat choice 
means for their conservation in Mozambique, we mapped gill nets during two dedicated aerial surveys along the Inhambane coast and counted gill nets in 1,323 boat-based surveys near Praia do Tofo. Our results show that, while whale sharks are capable of longdistance oceanic movements, they can spend a disproportionate amount of time in specific areas, such as along the southern Mozambique coast. The increasing use of drifting gill nets in this coastal hotspot for whale sharks is likely to be a threat to regional populations of this iconic species. 
1 Satellite tagging highlights the importance of productive Mozambican coastal

2 waters to the ecology and conservation of whale sharks

3 Christoph A. Rohner ${ }^{1 *}$, Anthony J. Richardson, ${ }^{2,3}$, Fabrice R. A. Jaine ${ }^{1,4,5}$, Michael B.

4 Bennett $^{6}$, Scarla J. Weeks ${ }^{7}$, Geremy Cliff ${ }^{8,9}$, David P. Robinson ${ }^{10}$, Katie E. Reeve-Arnold ${ }^{11}$

5 and Simon J. Pierce ${ }^{1}$

61 Manta Ray \& Whale Shark Research Centre, Marine Megafauna Foundation, Praia

7 do Tofo, Inhambane, Mozambique

82 CSIRO Marine and Atmospheric Research, EcoScience Precinct, Dutton Park QLD

9 4102, Australia

103 Centre for Applications in Natural Resource Mathematics (CARM), School of

11 Mathematics and Physics, The University of Queensland, St Lucia QLD 4072,

12 Australia

134 Sydney Institute of Marine Science, Mosman NSW 2088, Australia

145 Department of Biological Sciences, Macquarie University, North Ryde, NSW 2109 ,

15 Australia

166 School of Biomedical Sciences, The University of Queensland, St Lucia QLD 4072,

17 Australia

187 Biophysical Oceanography Group, School of Geography, Planning and Environmental

19 Management, The University of Queensland, St Lucia QLD 4072, Australia

208 Kwa-Zulu Natal Sharks Board, Private Bag 2, Umhlanga 4320, South Africa

$21{ }^{9}$ Biomedical Resource Unit, University of KwaZulu-Natal, Durban 4051, South Africa

$22{ }^{10}$ Shark Watch Arabia, Dubai, United Arab Emirates

$23{ }^{11}$ All Out Africa Marine Research Centre, Praia do Tofo, Inhambane, Mozambique

24 *Email: chris@marinemegafauna.org 


\section{Abstract}

26 The whale shark Rhincodon typus is an endangered, highly migratory species with a 27 wide, albeit patchy, distribution through tropical oceans. Ten aerial survey flights along 28 the southern Mozambican coast, conducted between 2004-2008, documented a 29 relatively high density of whale sharks along a $\sim 200 \mathrm{~km}$ stretch of the Inhambane 30 Province, with a pronounced hotspot adjacent to Praia do Tofo. To examine the 31 residency and movement of whale sharks in coastal areas around Praia do Tofo, where 32 they may be more susceptible to gill net entanglement, we tagged 15 juveniles with 33 SPOT5 satellite tags and tracked them for 2-88 days (mean $=27$ days) as they 34 dispersed from this area. Sharks travelled between 10 and 2,737 km (mean = $738 \mathrm{~km}$ ) 35 at a mean horizontal speed of $28 \pm 17.1 \mathrm{SD} \mathrm{km} \mathrm{day}{ }^{-1}$. While several individuals left shelf 36 waters and travelled across international boundaries, most sharks stayed in 37 Mozambican coastal waters over the tracking period. We tested for whale shark habitat preferences, using sea surface temperature, chlorophyll-a concentration and water depth as variables, by computing 100 random model tracks for each real shark based on their empirical movement characteristics. Whale sharks spent significantly more time in cooler, shallower water with higher chlorophyll-a concentrations than model sharks, 42 suggesting that feeding in productive coastal waters is an important driver of their movements. To investigate what this coastal habitat choice means for their conservation

44 in Mozambique, we mapped gill nets during two dedicated aerial surveys along the 45 Inhambane coast and counted gill nets in 1,323 boat-based surveys near Praia do Tofo. 46 Our results show that, while whale sharks are capable of long-distance oceanic movements, they can spend a disproportionate amount of time in specific areas, such as along the southern Mozambique coast. The increasing use of drifting gill nets in this coastal hotspot for whale sharks is likely to be a threat to regional populations of this 50 iconic species. 


\section{Introduction}

52 Knowledge of the movements of a species in space and time improves understanding of

53 its habitat use and ecology, can enhance conservation management, and allows

54 prediction of the species' response to changing conditions (Sims, 2010; Block et al.,

55 2011; Hays et al., 2016). It can, however, be technologically and logistically challenging

56 to study the movements of difficult-to-access species, such as wide-ranging marine

57 fishes. Recent improvements in the equipment available for marine animal tracking,

58 coupled with refined analytical techniques (Nathan et al., 2008; Block et al., 2011; Costa,

59 Breed \& Robinson, 2012), have made it easier to interpret both the movements and 60 motivation underpinning the spatial ecology of even highly-mobile species (Sims et al., 61 2006).

62 Whale sharks Rhincodon typus move thousands of kilometres horizontally (Hueter, 63 Tyminski \& de la Parra, 2013; Berumen et al., 2014; Hearn et al., 2016) and perform 64 vertical dives to $>1,900 \mathrm{~m}$ depth (Tyminski et al., 2015). Although they actively move and 65 do not simply follow surface ocean currents (Sleeman et al., 2010), ecological drivers of 66 their movements are poorly understood. As coastal aggregations of whale sharks, 67 including our study population off Mozambique, comprise mostly juveniles (Rohner et al., 68 2015b), reproduction is not likely to influence their movements during this life stage. 69 Avoiding predation is also not a likely factor driving the movements of these large $(>4 \mathrm{~m}$ 70 in length) sharks that have few natural predators (Rowat \& Brooks, 2012). Rather, prey 71 search behaviour is likely to be the major driver of their movement, as zooplankton, the 72 primary prey of whale sharks, are patchily distributed (Lalli \& Parsons, 1997) throughout 73 the species' tropical to warm temperate distribution (Rowat \& Brooks, 2012).

74 Whale sharks are sighted off Praia do Tofo in southern Mozambique throughout the year 75 (Rohner et al., 2013b; Haskell et al., 2015). Although some inter-annual site fidelity has 76 been observed (Rohner et al., 2015b), photo-identification data suggest a short mean 77 residency time (9 days) for this stretch of coast (Prebble et al. unpublished data). Where 78 they go, and the underlying drivers of this rapid turnover, remain uncertain. Although 79 whale sharks are also seen in nearby Tanzania, Seychelles and Djibouti, photo80 identification has shown limited connectivity among those sites (Norman et al. in press;

81 Brooks et al., 2010; Andrzejaczek et al., 2016). Despite their well-documented ability to 
82 move long distances (Hueter, Tyminski \& de la Parra, 2013; Hearn et al., 2016), 83 including from Praia do Tofo (Brunnschweiler et al., 2009), in the Indian Ocean there 84 have been few examples of whale sharks being re-sighted outside the geographic 85 region where they were first identified (Norman et al. in press). As most photo86 identification and tag deployment has taken place at aggregation sites dominated by 87 juvenile males, limited inference can be made about the behavior of the broader whale 88 shark population (Rohner et al., 2015b). Mature whale sharks (>800-900 cm long; Acuña-Marrero et al., 2014; Rohner et al., 2015a) may range further, and are likely to be 90 more oceanic, as few have been sighted at coastal aggregation sites (Hearn et al., 91 2016; Robinson et al., 2016; Ramírez-Macías et al., 2017).

92 There is a clear conservation imperative to understand the movement ecology of whale 93 sharks in southern Mozambique. Whale shark sightings at Praia do Tofo decreased by $9479 \%$ between 2005 and 2011 with local environmental parameters taken into 95 consideration (Rohner et al., 2013b), a trend that has continued following the conclusion 96 of that study (Pierce \& Norman, 2016). In the northern Mozambique Channel, following a 97 slight increase in sightings from the tuna purse-seine fleet between 1991-2000, there 98 was a decrease from 2000-2007 (Sequeira et al., 2013). In absolute terms, 600 99 sightings were reported from 1990s, decreasing to 200 from 2000-2007 (Sequeira et 100 al., 2014), and peak monthly sightings decreased by 50\% (Sequeira et al., 2014). 101 While large-scale oceanographic mechanisms may influence sightings (Rohner et al., 102 2013b), there are also fisheries-related captures and mortalities of whale sharks in the 103 region (Jonahson \& Harding, 2007; Capietto et al., 2014; Everett et al., 2015)

104 Mozambique ranks low on the global Human Development Index: $0.418=181$ of 188 105 countries (United Nations Development Programme, 2016). With over two thirds of 106 Mozambique's population living within $150 \mathrm{~km}$ of the coast, $\sim 50 \%$ of their protein intake 107 comes from fish (Hara, Deru \& Pitamber, 2007). Gill net use has been increasing in 108 Mozambique since the cessation of conflict in 1992 (WWF Eastern African Marine 109 Ecoregion, 2004), and nets have been actively distributed by fisheries officials in some 110 areas of the country to move fishing effort away from sensitive inshore nursery habitats 111 (Leeney, 2017). Floating gill nets, extending from the beach to $200 \mathrm{~m}$ offshore, pose a 112 threat to marine megafauna species swimming along this coast. While few formal data 
113 are available, these gill nets are routinely used off the Inhambane coast. At least two

114 whale shark mortalities have been observed in this area, both sighted opportunistically

115 (S. Pierce pers. obs.), and entanglements are commonly reported (Speed et al. 2008; S.

116 Pierce unpubl. data). Whale sharks are a valuable focal species in marine tourism off

117 Praia do Tofo and adjacent areas (Pierce et al., 2010; Tibiriçá et al., 2011; Haskell et al.,

118 2015). The species received formal protection in Mozambique and, separately, were

119 listed on Appendix I of the Convention of Migratory Species - which requires prohibition

120 of take by signatory countries (which includes Mozambique) - during 2017.

121 Here we examine the regional movements and underlying environmental drivers of 122 whale shark activity in Mozambique. We use aerial surveys, satellite telemetry and 123 randomised model shark tracks to establish their activity hotspots in this region, and test 124 the hypothesis that they preferentially spend most of their time in shallow coastal waters. 125 With the limited data available, we also assess the potential for interaction with the 126 coastal gill net fishery along the Inhambane coast.

\section{Materials and Methods}

128 Aerial surveys for whale sharks

129 Data on the spatial distribution of whale sharks in southern Mozambique were acquired 130 from aerial survey flights conducted by the KwaZulu-Natal Sharks Board in a top wing 131 aircraft, flown $305 \mathrm{~m}$ (1,000 ft) above sea level at $184 \mathrm{~km} \mathrm{~h}^{-1}$ (100 knots) (Fig. 1). Two 132 observers recorded time and GPS coordinates for each whale shark within $\sim 750 \mathrm{~m}$ of 133 the coast during 10 regional flights between 2004 and 2008 in February and March.

134 Flights were conducted when viewing conditions were optimal, characterised by light 135 winds and minimal cloud (see full methods in Cliff et al., 2007). For aggregations of 136 multiple individuals, central coordinates were used when only the start and end GPS 137 position were recorded. Aerial surveys have the limitations that whale sharks can only 138 be seen by observers in surface waters, but the species also occupies deeper habitats 139 in which they would not be able to be sighted. Logistical and cost constraints also meant 140 that a relatively small number of aerial surveys were available for this study. Aerial 141 survey data did not temporally match satellite tagging data. Spatial data were mapped in 142 ArcGIS 10.2.1 in $1 \mathrm{~km}^{2}$ grids and whale shark numbers expressed per $\mathrm{km}^{2}$. 


\section{Study area and whale shark tagging}

144 Fifteen juvenile whale sharks, comprising 12 males and 3 females ranging from 540-

$145865 \mathrm{~cm}$ total length (TL), were equipped with Smart Position or Temperature 146 Transmitting (SPOT5) tags from Wildlife Computers, and tracked between November

1472010 and January 2012. All tagged sharks were photographically identified based on

148 their spot pattern posterior to the gills and matched on, or added to, the Wildbook for

149 Whale Sharks global whale shark database (www.whaleshark.org; Arzoumanian,

150 Holmberg \& Norman, 2005). Sex was determined based on the presence (male) or

151 absence (female) of claspers. Male maturity status was assigned according to clasper

152 length and thickness (Rohner et al., 2015b). Longer-term (pre- and post-tagging) site

153 fidelity of these sharks was assessed through to the end of 2016 via photo-identification

154 submissions to the Wildbook database. Length estimates were derived from laser 155 photogrammetry and visual size assessments, with an estimated error of $\pm 50 \mathrm{~cm}$ 156 (Rohner et al., 2011). All tags were deployed immediately off Praia do Tofo in southern

157 Mozambique $\left(23.85^{\circ} \mathrm{S}, 35.54^{\circ} \mathrm{E}\right)$. The tag's float was covered with dark antifouling paint

158 to minimise bio-fouling and make it less obvious to predatory fishes. The tag was

159 connected to a $\sim 5 \mathrm{~cm}$ titanium dart (Wildlife Computers) via a $\sim 180 \mathrm{~cm}$ tether. The first

160 five tags had a stainless steel game-fishing swivel $30 \mathrm{~cm}$ from the dart, before it became

161 evident from retrieval of shed tags that the swivel was a weak point and was therefore

162 not used in later deployments. The first three tags used stainless steel wire as a short

163 tether connecting the dart with the swivel; the remainder of the tether (and the entire

164 tether in later deployments) comprised Dyneema braid. The dart was inserted into the

165 skin at the posterior base of the $1^{\text {st }}$ dorsal fin for the first three tags, using a $200 \mathrm{~cm}$ hand

166 spear. Tag retention was improved on subsequent deployments by implanting the dart

167 slightly further anteriorly, so that the tag floated adjacent to the $1^{\text {st }}$ dorsal fin. No animal

168 was restrained, caught or removed from its natural habitat for the purpose of this study.

169 Whale shark tagging was compliant with ethics guidelines from the University of

170 Queensland's Animal Ethics Committee and was conducted under their approval

171 certificate GPEM/186/10/MMF/ WCS/SF.

172 SPOT5 tags are positively buoyant and communicate with the ARGOS system

173 (www.argos-system.org) when the wet/dry sensor is exposed to air. Tags were 
174 programmed for a daily limit of 300 transmissions to save battery power in case of 175 extended tag retention. Transmitted data included tag location and accuracy (location 176 classes $3,2,1,0, A, B, Z$ ), as well as sea surface temperature (SST) at the time of 177 transmission. We used standard methods by Hearn et al. (2013; time of transmissions 178 and time-at-temperature data) to determine when a tag detached from the shark, and 179 removed the floating portion of the tracks before analyses were conducted. We only 180 used location classes 3, 2 and 1 for further analyses. Estimated precision for location 181 classes 3, 2 and 1 are theoretically $0.15,0.35$ and $1.00 \mathrm{~km}$ (ARGOS), but are larger 182 when the tag is deployed on an animal at sea, with mean errors of $0.49,0.94$ and 1.10 $183 \mathrm{~km}$, respectively (Costa et al., 2010). More than half of all transmissions ( $n=1,930)$ 184 were characterised by ARGOS location classes 3, 2 and 1 and allowed accurate position 185 estimation. Track distance was measured as the sum of the straight-line distances 186 between two adjacent locations. Nine tags also recorded the proportion of time spent in 18712 pre-defined temperature bins during 1,5 or $6 \mathrm{~h}$ time intervals with data recorded at 188 05:00h, 06:00h, 11:00h, 17:00h, 18:00h and 23:00h. These time-at-temperature (TAT) 189 data are limited to a period preceding a transmission via satellite, and hence do not 190 reflect the full temperature range experienced by the tagged whale sharks. Available TAT 191 data ranged from $36-100 \%$ of tracking days for individual sharks ( mean $=81 \%$ ) and 173 192 of 262 days in total for all sharks combined. SST and chlorophyll-a concentration (Chl-a) 193 data were derived from the Moderate Resolution Imaging Spectroradiometer website 194 (MODIS; modis.gsfc.nasa.gov) to produce monthly day- and night-merged SST and Chl195 a time series at $1 \mathrm{~km}^{2}$ spatial resolution for the period sharks were tagged. Chl-a was 196 used as a proxy for zooplankton availability. Despite a possible lag in zooplankton 197 abundance in response to a phytoplankton bloom (Plourde \& Runge, 1993; Flagg, 198 Wirick \& Smith, 1994), phyto- and zooplankton abundance is often correlated 199 (Hutchinson, 1967; Richardson \& Schoeman, 2004; Ware, 2005) and has been used 200 similarly in previous studies on planktivorous elasmobranchs (Sims et al., 2003; 201 Sleeman et al., 2007; Graham et al., 2012). To investigate drivers of coastal occurrences 202 of whale sharks, SST values were extracted for one coastal location near Praia do Tofo $203\left(23.85^{\circ} \mathrm{S}, 35.62^{\circ} \mathrm{E}, 36 \mathrm{~m}\right.$ depth) and one further offshore $\left(23.85^{\circ} \mathrm{S}, 36.00^{\circ} \mathrm{E}, 988 \mathrm{~m}\right.$ 204 depth, $\sim 45 \mathrm{~km}$ from the coast). SST and Chl-a values were also extracted for all 205 positions with a location class 3, 2 or 1 from tracked whale sharks and for all positions 
206 from random model sharks (see below). A nine-month mean was produced for SST and 207 Chl-a, encompassing all months when tagged sharks were tracked. Bathymetric data 208 were derived from the NOAA ETOPO2 dataset at a $\sim 1 \mathrm{~km}$ resolution.

209 Random model sharks

210 We generated random model tracks ('model sharks') for each tagged shark ('real 211 sharks') based on characteristics of the real tracks, similar to analyses conducted on 212 basking sharks Cetorhinus maximus by Sims et al. (2006). Input data for this analysis 213 were observed locations with accuracy classes 3, 2 and 1, and a step was defined as 214 the most direct, straight line between successive locations. Each model shark had the 215 same starting location, overall track distance, and step-length frequencies as the real 216 whale shark, but the order of steps was randomised. Real whale sharks often swam 217 along the coast (Supplementary Fig. 1), but as we had no a priori expectation whether 218 sharks would move north or south or offshore, our random sharks took a random angle 219 between steps while constraining the total length of the track to that of the real sharks. 220 For a step that crossed land, or extended beyond the study area boundary (20-30 ${ }^{\circ} \mathrm{S}, 31$ $\left.22140^{\circ} \mathrm{E}\right)$, another random turning angle was taken. The simulation was run in $R(R$ 222 Development Core Team, 2008) and sets of 100 model shark tracks were generated for 223 each whale shark (Supplementary Fig. 2). The aim of the model sharks was not to mimic 224 the real sharks, but to test whether the real sharks had a preference for locations on the 225 regional shelf (0-200 $\mathrm{m}$ depth, $\left.22.17^{\circ} \mathrm{S}-24.51^{\circ} \mathrm{S}\right)$, or for certain SST or chl-a conditions.

\section{Kernel density estimation analysis}

227 All transmitted tag locations and modelled shark locations were input to ArcGIS 10.2.1.

228 The "kernel density tool" was used to calculate percentile kernels of location density. 229 Kernel density estimates were produced following MacLeod (2013), with a search radius 230 of $5 \mathrm{~km}$ and the outlying locations falling into the $2.5 \%$ kernel removed. Kernel density 231 estimation analysis is based on transmitted locations and cannot consider the periods of 232 the overall tracking duration when no locations were transmitted, which equaled 183 of 233403 days in our dataset.

\section{Gill nets}


235 Gill nets in the study area were set and drifting at the surface perpendicular to the 236 beach. Net dimensions varied among fishing communities in the region, but were 237 typically $20-200 \mathrm{~m}$ long, 5-8 $\mathrm{m}$ deep, and had a mesh size of 5-20 cm. Nets were made 238 from monofilament or thin rope. Whale sharks are not specifically targeted in 239 Mozambique, but nets with a larger mesh size present an entanglement risk. Locations 240 of these gill nets along the $\sim 200 \mathrm{~km}$ of coastline between Zàvora to Pomene were 241 recorded with a GPS during two aerial survey flights in May 2016. A transect was flown 242 along the coast in a Bat Hawk LSA at $244 \mathrm{~m}(800 \mathrm{ft})$ above sea level at 60 knots and $243 \sim 300-500 \mathrm{~m}$ from the beach. To assess the trend in gill net use over time, we used 244 survey data off the Praia do Tofo area itself. We conducted 1,323 boat-based surveys 245 from 2012 to 2015 , during which gill nets were counted on the way to dive sites located 246 along a $40 \mathrm{~km}$ stretch of coast. Surveys were on average $21.3 \mathrm{~km}$ long, but survey 247 design was influenced by which sites the dive company accessed at the time. We 248 calculated the number of gill nets per $1,000 \mathrm{~km}$ of survey track for each year over the 4249 year period. The gill net surveys did not temporally match with the whale shark tracking 250 data, as pre-2012 gill nets were not counted because they were rarely in use around 251 Praia do Tofo.

\section{Results}

253 Whale shark aggregation

254 Flight observers recorded a total of 202 whale sharks in southern Mozambique during 255 the 10 aerial survey transects between 2004 and 2008, with a mean of 3.4 individuals $256100 \mathrm{~km}^{-1}$. The focal area of whale shark sightings was the $200 \mathrm{~km}$ stretch of coastline 257 between Zàvora and Pomene, with the peak at Praia do Tofo (Fig. 1). Several large 258 aggregations were observed near Praia do Tofo, with the largest being 51 individuals 259 sighted on 1 March 2005.

260 Gill nets were recorded during aerial surveys in the same region where whale shark 261 sightings were highest between Zàvora and Pomene (Fig. 1). In the immediate area 262 around Praia do Tofo, boat-based surveys showed that gill net usage increased $\sim 7$ times 263 from 0.95 to 6.44 nets per $1,000 \mathrm{~km}$ survey track from 2012 to 2015. 
265 SPOT5 tags remained on the sharks for 2-88 days (mean \pm SD $=27 \pm 28.1$ d) and 266 transmitted locations on $55 \%$ of days of the combined tracking duration (Table 1). Whale 267 sharks travelled at a mean speed of $28 \mathrm{~km}^{-1}$ day $^{-1}\left(\right.$ median $=26.1 \mathrm{~km}^{-1}{ }^{-1}$, range $=2.6-$ $26870.1 \mathrm{~km} \mathrm{day}^{-1}$ ), similar to whale sharks tracked elsewhere (Table 2). The longest 269 straight-line, along-track distances were 2,737 km over 84 days, and 2,447 km over 88 270 days (Table 1). All sharks remained within the southern Mozambique Channel and 271 eastern South African waters while tagged (Fig. 2). Seven sharks (47\%) moved offshore 272 for at least part of their track, while the other eight (53\%) remained on the shelf near the 273 coast. Tracking duration did not influence whether sharks went offshore or stayed 274 coastal $(t=-1.11, d f=11.4, p=0.29)$. Season may have played a role, with a greater 275 proportion of sharks moving offshore in summer ( 3 out of 3 ), less in winter ( 3 of 5 ), and a 276 lower proportion again in spring ( 2 of 7 ), although numbers were too small to be 277 conclusive (Fig. 2). Whale sharks travelling away from the coast swam significantly 278 further (mean $=1,137 \mathrm{vs} .282 \mathrm{~km}$ ) and faster $\left(\right.$ mean $=43 \mathrm{vs.} 20 \mathrm{~km}^{-1 a y^{-1}}$ ) than those 279 that stayed in coastal waters $(t=2.29, \mathrm{df}=8.3, \mathrm{p}=0.05$, and $\mathrm{t}=2.46$, $\mathrm{df}=11.1, \mathrm{p}=$ 280 0.031, respectively). Of the five sharks tagged within a short time period (9-11 July 281 2011), one initially swam northward along the coast and four swam southward. Apart 282 from MZ-463, which travelled to northern South Africa, these sharks stayed in coastal 283 waters and swam past Praia do Tofo again after 3-13 days.

284 Home range and random model sharks

285 The kernel density estimation analysis of whale shark tracks showed that the main 286 hotspot of whale shark activity was between Zàvora and Praia do Tofo, with a second, 287 less intense hotspot around the Pomene headland, $100 \mathrm{~km}$ north of Praia do Tofo (Fig. 288 3a). High-use areas were on the continental shelf. By contrast, model sharks spread 289 from Praia do Tofo and their high activity zone included areas off the continental shelf 290 (Fig. 3b). Overall, whale sharks spent significantly more time on the regional shelf (85\%) 291 than model sharks $\left(15 \% ; x^{2}=1239.6, d f=15, p<0.001\right)$. An example is shark MZ-241, 292 which swam north along the coast, then briefly headed offshore, before returning to 293 coastal waters south of Praia do Tofo (Sup. Fig. 2). This was one of 10 sharks that spent 294 more time on the shelf than any of the corresponding 100 model tracks for each real 295 shark. Only MZ-562 (8\% of a 3-day track) and MZ-463 (26\% of a 10-day track) spent 296 less time on the regional shelf than half of the model sharks. 
297 Tagged sharks transmitted their position on 30 separate days while they were in the 298 immediate whale shark search area off Tofo $\left(23.85^{\circ} \mathrm{S}-23.93^{\circ} \mathrm{S}\right)$, excluding detections 299 from the day of tag deployment. Only two sharks, on two separate days, were re-sighted 300 in regular visual surveys using photo-identification during the period of tag deployment. 301 One of these had its tag entangled in a fishing line, causing the tag to sit under the 302 shark's body and preventing it from breaking the surface to transmit, so we removed the 303 tag and line. Photo-identification data indicated that most of the tagged sharks $(67 \%)$ 304 returned to the region after losing their tag, with these sharks being sighted on 2-11 305 unique days (mean $=4.8 \pm 2.6$ days) over $1-6$ unique calendar years between 2005 and 3062016 (mean $=3.2 \pm 1.4$ years).

307 Temperature and chlorophyll-a distributions

308 Tag-derived temperature data showed whale sharks moved through surface 309 temperatures between $18.5-29.7^{\circ} \mathrm{C}$, with a mean of $23.9 \pm 1.51^{\circ} \mathrm{C}$. Half of all 310 transmissions were from a narrow range of $22-24^{\circ} \mathrm{C}$ waters, and $>95 \%$ were from $21-$ $31127^{\circ} \mathrm{C}$ waters (Fig. 4a). This temperature distribution is at least partly a result of the 312 seasonal bias in tagging, with most transmissions in winter and spring when coastal and 313 offshore temperatures were relatively cool (Fig. 4b).

314 Whale sharks spent more time in cooler water with higher Chl-a than model sharks (Fig. $3155 a, b)$. Mean Chl-a was significantly higher for whale sharks (mean $=1.18 \pm 2.74 \mathrm{mg} \mathrm{m}^{-3}$ ) 316 than model sharks (mean $=0.27 \pm 0.79 \mathrm{mg} \mathrm{m}^{-3} ; \mathrm{t}=-9.38, \mathrm{df}=803.3, \mathrm{p}<0.001$ ). Mean 317 satellite-derived SST was significantly cooler for whale shark locations (mean $=24.23 \pm$ $\left.3181.59^{\circ} \mathrm{C}\right)$ than for model sharks $\left(24.49 \pm 1.62^{\circ} \mathrm{C} ; \mathrm{t}=4.28\right.$, df $=679.4, \mathrm{p}<0.001$; Fig. $\left.5 b\right)$.

319 Chl-a and SST distributions were also significantly different between whale sharks and 320 model sharks $\left(X^{2}=549.1\right.$, $d f=8,<0.0001$ and $X^{2}=297.5$, $d f=10, p<0.0001$, 321 respectively). Coastal shelf waters had higher Chl-a (Fig. 5c) and were cooler (Fig. 5d) 322 than offshore waters over the 9-month duration of this study. 
324 Temperatures recorded in binned intervals of up to $24 \mathrm{~h}$ prior to each transmission 325 indicated that some of the tagged sharks made pronounced vertical movements. 326 Combining data from all tags, the temperature bin extremes ranged from $5.1-10^{\circ} \mathrm{C}$ up to $32727.6-29^{\circ} \mathrm{C}$. The largest proportion of time (64\%) was spent in $22.6-25^{\circ} \mathrm{C}$ water. Overall, 328 whale sharks experienced a wider temperature range when they were off the continental 329 shelf as opposed to inshore (Fig. 6). When on the shelf, they spent the majority of time $330(76 \%)$ in $22.6-25^{\circ} \mathrm{C}$ water, while the coldest temperatures recorded from shelf waters 331 were in the $15.1-17.5^{\circ} \mathrm{C}$ bin $(0.1 \%$ of time $)$. By contrast, when off the shelf, sharks spent 332 the most time in warmer $25.1-27.5^{\circ} \mathrm{C}$ water, while the coldest offshore temperatures 333 were in the $5.1-10.0^{\circ} \mathrm{C}(0.3 \%$ of time $)$ and in the $10.1-15.0^{\circ} \mathrm{C}$ bins $(7.9 \%)$.

\section{Discussion}

335 Whale sharks tagged at Praia do Tofo moved widely in southern Mozambican and 336 eastern South African waters. Although the duration of tag transmission was relatively 337 short for most sharks, they spent a disproportionately high amount of time in regional 338 shelf waters between Zàvora and Pomene. This is of concern for regional whale shark 339 conservation, as gill net use is rapidly increasing in the same coastal area where tagged 340 whale sharks spent a lot of time, leading to a higher chance of net entanglement and 341 mortality. Whale sharks moved through water with higher Chl-a than simulated model 342 sharks, suggesting that foraging is a major driver of their movements in this region.

343 The coastal whale shark hotspot in southern Mozambique

344 The primary activity hotspot for tagged whale sharks was a $\sim 200 \mathrm{~km}$ stretch of shelf 345 waters along the coast from Zàvora to Praia do Tofo, and also around Pomene. This 346 agrees with our aerial survey data from 2004-2008, despite the temporal mismatch of 347 the two datasets, which strengthens the importance of this area for whale sharks. One 348 caveat is that both technologies require the sharks to be in surface waters to be 349 detected, and whale sharks may also be abundant elsewhere in deeper water but 350 remain undetected. The observed hotspot was not the result of random movement, or a 351 bias due to the tagging site, as model sharks spent significantly less time on the 352 continental shelf than real whale sharks. In addition, long-term whale shark sightings at 353 Praia do Tofo fluctuated, but did not have a seasonal trend (Rohner et al., 2013b). 
354 Hence, while our tracks were relatively short and did not span the whole year, the 355 general pattern may apply throughout the year. The narrow shelf waters around Praia do 356 Tofo were a preferred habitat for whale sharks in the region in our study, which is further 357 corroborated by photo-identification and tourism studies (Pierce et al., 2010; Haskell et 358 al., 2015; Rohner et al., 2015b). However, our tagging data also show that the core use 359 area for whale sharks in Mozambique is larger than previously reported, and larger than 360 in some other, more defined whale shark aggregations that exploit specific and localised 361 ephemeral prey sources or biological events (Heyman et al., 2001; Robinson et al., 362 2013; Rohner et al., 2015a). For example, the 50\% kernel densities covered $185 \mathrm{~km}^{2}$ in 363 Mozambique compared to just $66 \mathrm{~km}^{2}$ in Qatar (Robinson et al. in 2017).

364 Eight whale sharks (53\% of those tagged) returned to the tagging site during tag 365 attachment after significant initial $(>50 \mathrm{~km})$ movement away from the site, mostly along 366 the coast. Only two of these individuals were photographically recaptured, despite close 367 to daily survey effort in good conditions for potential resightings (S. Pierce unpubl. data). 368 This further stresses the importance of sightings-independent methods for assessing 369 whale shark residency, as detectability can be low, even when regular visual surveys are 370 performed (Cagua et al., 2015; Andrzejaczek et al., 2016). Eight of the 15 tagged whale 371 sharks were photographically re-sighted at Praia do Tofo after losing their tags, 372 indicating some degree of site fidelity. Elsewhere, whale sharks also return to other 373 aggregation sites, as determined by photo-ID techniques (Holmberg, Norman \& 374 Arzoumanian, 2009; Rowat et al., 2011), and their site fidelity may be more prevalent 375 than expected from sightings data (Cagua et al., 2015).

\section{Preference for shelf waters}

377 During the 8 months of the year (Jul-Feb) that whale sharks were tracked, over a 378 combined duration of 403 days, whale sharks actively chose continental shelf waters 379 that were cooler and had higher Chl-a than the modelled sharks that moved randomly. 380 While shallower, cooler water and higher Chl-a co-vary in our study region, the bigger 381 difference in Chl-a between real and model sharks indicated that they mostly selected 382 Chl-a. Their preference for cooler shelf waters with higher Chl- $a$ is thus likely to be 383 related to foraging activities. Even though whale sharks do not directly feed on 384 phytoplankton, and there is often a lag between the timing of phytoplankton and 
385 zooplankton blooms (Plourde \& Runge, 1993; Flagg, Wirick \& Smith, 1994), high 386 phytoplankton biomass is often indicative of high zooplankton densities (Hutchinson, 387 1967; Richardson \& Schoeman, 2004; Ware, 2005). Whale shark sightings (Sleeman et 388 al., 2007) and the abundance of other large marine animals have previously been 389 correlated with Chl-a (Zagaglia, Lorenzzetti \& Stech, 2004; Block et al., 2011; Graham et 390 al., 2012; Jaine et al., 2012). We suggest that the juvenile whale sharks at Praia do Tofo 391 that stay on the shelf do so to take advantage of high local food availability. Whale 392 sharks off Praia do Tofo have been seen feeding $\sim 20 \%$ of their time during daylight 393 hours (Pierce et al., 2010). Stomach contents of whale sharks from southern 394 Mozambique and northern South Africa were dominated by mysids, a group of demersal 395 zooplankton that emerge into surface waters at night (Rohner et al., 2013a). Shallow 396 coastal waters also have a high abundance of other demersal zooplankton (Alldredge \& 397 King, 1977; Ohlhorst, 1982). This suggests that Mozambican coastal waters are 398 important foraging grounds for these juvenile whale sharks, perhaps more at night than 399 during the day.

400 Tag-recorded temperature data further support the hypothesis that whale sharks often 401 remain in shelf waters to exploit foraging opportunities. When off the shelf, in deeper 402 waters, whale sharks experienced a broader temperature range that extended to cooler 403 temperatures than those recorded from the surface. By contrast, the temperature range 404 recorded for locations on the shelf were similar to surface water temperatures. This 405 indicated that little diving behaviour took place, as shelf waters in the Mozambique 406 Channel get significantly cooler at depth (Lamont et al., 2010; Malauene et al., 2014; 407 Rohner et al., 2017). This suggested that whale sharks increased their vertical 408 movement when off the shelf. Whale sharks dive to bathypelagic depths $(>1,000 \mathrm{~m})$, as 409 has been demonstrated with pressure-recording tags (Brunnschweiler et al., 2009; 410 Tyminski et al., 2015). One whale shark tagged near Praia do Tofo undertook most deep 411 dives in the southern Mozambique Channel during the day, when zooplankton is often 412 found at depth (Loose \& Dawidowicz, 1994), suggesting that these dives might have 413 been related to foraging (Brunnschweiler et al., 2009). Results from biochemical dietary 414 studies have suggested that whale sharks may feed on meso- and bathypelagic 415 crustaceans and fishes, among other prey (Rohner et al., 2013a). Since temperatures of $4164.2^{\circ} \mathrm{C}, 5.5^{\circ} \mathrm{C}$ and $9.2^{\circ} \mathrm{C}$ were recorded at $1,264 \mathrm{~m}, 1,092 \mathrm{~m}$ and $1,087 \mathrm{~m}$ depth 
417 respectively (Brunnschweiler et al., 2009), one of our tagged sharks, MZ-463, may have 418 dived to depths of around $1,000 \mathrm{~m}\left(5.1-10^{\circ} \mathrm{C}\right.$ bin), potentially to feed.

419 Whale sharks swam at a mean speed of $\sim 28 \mathrm{~km} \mathrm{~d}^{-1}$ which is within the large range of 420 swimming speeds reported in previous studies. Larger sharks (>900 cm TL) tagged in 421 other locations exhibited similar speeds to juveniles (Wilson et al., 2006; Hearn et al., 422 2016), and the difference in distance covered per day among studies is likely to be 423 primarily influenced by the sharks' behaviour (feeding vs. migrating) rather than their 424 size, at least for sharks $>400 \mathrm{~cm}$ TL. Similarly, total mean track distance in different 425 studies is likely to be influenced by both tracking duration and whale shark behaviour.

426 Conservation and management implications

427 This study supports the results from other tracking studies that show whale sharks 428 routinely swim long distances and cross international boundaries. Offshore areas were 429 used by some of the tagged individuals and may be important habitats for the species, 430 particularly large, mature animals (Hearn et al., 2016) that are seldom seen at coastal 431 aggregations (Rowat \& Brooks, 2012; Rohner et al., 2015b; Ramírez-Macías et al., 432 2017). Results of this study indicate that southern Mozambican whale sharks routinely 433 cross into South African waters, in addition to some interchange with Madagascar 434 (Brunnschweiler et al., 2009), the Seychelles (Andrzejaczek et al., 2016) and Tanzania 435 (Norman et al. in press). A coordinated regional approach to managing the species' 436 conservation in the Western Indian Ocean is therefore of importance, given the 437 transnational boundaries crossed by individual sharks, and their occupancy of 438 international waters.

439 That notwithstanding, these juvenile whale sharks spent a large proportion of their time 440 on the shelf adjacent to Praia do Tofo, indicating that this is a particularly important 441 habitat within the region. Drifting gill nets are set in the same areas where the whale 442 shark activity hotspot was recorded. Furthermore, their use in the Praia do Tofo area has 443 increased over recent years. While the satellite tracking dataset (2010-2012) does not 444 temporally match with the gill net abundance dataset (2012-2015), we suggest that the 445 spatial overlap of the whale shark hotspot and the increasing gill net use in the area 
446 raises concerns, especially considering the regular north-south movement of whale 447 sharks close to the coast that is likely to bring them in contact with these nets. However, 448 concomitant data on gill net numbers and locations and the distribution of whale sharks 449 would be needed to quantify the risk to whale sharks. Other threatened species, such as 450 manta rays, may also be affected by this fishery (Rohner et al., 2017). There are few 451 available data on catch and injury rates along this remote coast, although multiple 452 mortalities from gill nets and injuries characteristic of net entanglement have been 453 reported from the Inhambane Province (Speed et al., 2008, S. Pierce unpubl. data). 454 Interview-based surveys with fishing communities are presently underway to provide 455 more information on catches. Whale sharks within the Indian Ocean are listed as 456 'Endangered' on the IUCN Red List of Threatened Species (Pierce \& Norman, 2016), 457 and they are locally important to a burgeoning marine tourism industry (Pierce et al., 458 2010; Tibiriçá et al., 2011; Haskell et al., 2015). The lack of habitat-level protection, 459 coupled with poor regulation of inshore fisheries in Mozambique, is a clear threat to this 460 population.

\section{Acknowledgements}

462 We thank Clare Prebble and Peter Bassett, along with other volunteers from the Marine 463 Megafauna Foundation (MMF) for their assistance in the field. We thank the people who 464 found and returned some of the tags. We gratefully acknowledge the NASA Ocean 465 Biology Processing Group for provision of Moderate Resolution Imaging 466 Spectroradiometer satellite data. Janneman Conradie and Joshua Axford from MMF 467 conducted the gill net aerial surveys and Ross Newbigging (All Out Africa) and Jessica 468 Williams (Moz Turtles) helped compile the gill net visual survey data. We thank David 469 Johnston, Jeremy Kiszka and one anonymous reviewer for their constructive comments 470 on our submitted manuscript. Some maps were created using ArcGIS software by Esri, 471 please visit www.esri.com. We acknowledge the use of free vector and raster map data 472 sourced from www.naturalearthdata.com.

\section{References}

474 Acuña-Marrero D., Jiménez J., Smith F., Doherty PF., Hearn A., Green JR., Paredes475 Jarrín J., Salinas-de-León P. 2014. Whale shark (Rhincodon typus) seasonal 
476

477

478

479

480

481

482

483

484

485

486

487

488

489

490

491

492

493

494

495

496

497

498

499

500

501

502

503

504

505

506

507

508

presence, residence time and habitat use at Darwin Island, Galapagos Marine Reserve. PLOS ONE 9:e115946. DOI: 10.1371/journal.pone.0115946.

Alldredge AL., King JM. 1977. Distribution, abundance, and substrate preferences of demersal reef zooplankton at Lizard Island Lagoon, Great Barrier Reef. Marine Biology 41:317-333. DOI: 10.1007/BF00389098.

Andrzejaczek S., Meeuwig J., Pierce S., Davies T., Fisher R., Meekan M. 2016. The ecological connectivity of whale shark aggregations in the Indian Ocean: a photoidentification approach. Royal Society Open Science 3:160455. DOI: 10.1098/rsos.160455.

Arzoumanian Z., Holmberg J., Norman B. 2005. An astronomical pattern-matching algorithm for computer-aided identification of whale sharks Rhincodon typus. Journal of Applied Ecology 42:999-1011. DOI: 10.1111/j.1365-2664.2005.01117.x.

Berumen ML., Braun CD., Cochran JEM., Skomal GB., Thorrold SR. 2014. Movement patterns of juvenile whale sharks tagged at an aggregation site in the Red Sea. PLoS ONE 9:e103536. DOI: 10.1371/journal.pone.0103536.

Block BA., Jonsen ID., Jorgensen SJ., Winship AJ., Shaffer SA., Bograd SJ., Hazen EL., Foley DG., Breed GA., Harrison A-L., Ganong JE., Swithenbank A., Castleton M., Dewar H., Mate BR., Shillinger GL., Schaefer KM., Benson SR., Weise MJ., Henry RW., Costa DP. 2011. Tracking apex marine predator movements in a dynamic ocean. Nature 475:86-90. DOI: 10.1038/nature10082.

Brooks K., Rowat D., Pierce SJ., Jouannet D., Vely M. 2010. Seeing spots: Photoidentification as a regional tool for whale shark identification. Western Indian Ocean Journal of Marine Science 9:185-194.

Brunnschweiler JM., Baensch H., Pierce SJ., Sims DW. 2009. Deep-diving behaviour of a whale shark Rhincodon typus during long-distance movement in the western Indian Ocean. Journal of Fish Biology 74:706-714. DOI: 10.1111/j.10958649.2008.02155.x.

Cagua EF., Cochran JEM., Rohner CA., Prebble CEM., Sinclair-Taylor TH., Pierce SJ., Berumen ML. 2015. Acoustic telemetry reveals cryptic residency of whale sharks. Biology Letters 11:20150092-. DOI: 10.1098/rsbl.2015.0092.

Capietto A., Escalle L., Chavance P., Dubroca L., Delgado de Molina A., Murua H., Floch L., Damiano A., Rowat D., Merigot B. 2014. Mortality of marine megafauna induced by fisheries: Insights from the whale shark, the world's largest fish. Biological 
510 Cliff G., Anderson-Reade MD., Aitken AP., Charter GE., Peddemors VM. 2007. Aerial 511 census of whale sharks (Rhincodon typus) on the northern KwaZulu-Natal coast, 512 South Africa. Fisheries Research 84:41-46. DOI: 10.1016/j.fishres.2006.11.012.

513 Costa DP., Breed GA., Robinson PW. 2012. New insights into pelagic migrations: 514 Implications for ecology and conservation. Annual Review of Ecology, Evolution, and Systematics 43:73-96. DOI: 10.1146/annurev-ecolsys-102710-145045.

Costa DP., Robinson PW., Arnould JPY., Harrison A-L., Simmons SE., Hassrick JL.,

534 Graham RT., Witt MJ., Castellanos DW., Remolina F., Maxwell S., Godley BJ., Hawkes 535 LA. 2012. Satellite tracking of manta rays highlights challenges to their conservation. PLoS ONE 7:e36834. DOI: 10.1371/journal.pone.0036834.

\section{Republic of Mozambique.}

539 Haskell PJ., McGowan A., Westling A., Méndez-Jiménez A., Rohner CA., Collins K., 540 Rosero-Caicedo M., Salmond J., Monadjem A., Marshall AD., Pierce SJ. 2015. 541 Monitoring the effects of tourism on whale shark Rhincodon typus behaviour in 
542 Mozambique. Oryx 49:492-499. DOI: 10.1017/S0030605313001257.

543 Hays GC., Ferreira LC., Sequeira AMM., Meekan MG., Duarte CM., Bailey H., Bailleul 544 F., Bowen WD., Caley MJ., Costa DP., Eguíluz VM., Fossette S., Friedlaender AS., 545 Gales N., Gleiss AC., Gunn J., Harcourt R., Hazen EL., Heithaus MR., Heupel M., 546 Holland K., Horning M., Jonsen I., Kooyman GL., Lowe CG., Madsen PT., Marsh H., Phillips RA., Righton D., Ropert-Coudert Y., Sato K., Shaffer SA., Simpfendorfer CA., Sims DW., Skomal G., Takahashi A., Trathan PN., Wikelski M., Womble JN., Thums M. 2016. Key questions in marine megafauna movement ecology. Trends in Ecology \& Evolution. DOI: 10.1016/j.tree.2016.02.015.

Hearn AR., Green JR., Espinoza E., Peñaherrera C., Acuña D., Klimley a. 2013. Simple criteria to determine detachment point of towed satellite tags provide first evidence of return migrations of whale sharks (Rhincodon typus) at the Galapagos Islands, Ecuador. Animal Biotelemetry 1:11. DOI: 10.1186/2050-3385-1-11.

Hearn AR., Green J., Román MH., Acuña-Marrero D., Espinoza E., Klimley AP. 2016. Adult female whale sharks make long-distance movements past Darwin Island (Galapagos, Ecuador) in the Eastern Tropical Pacific. Marine Biology 163:214. DOI: 10.1007/s00227-016-2991-y.

Heyman W., Graham R., Kjerfve B., Johannes R. 2001. Whale sharks Rhincodon typus aggregate to feed on fish spawn in Belize. Marine Ecology Progress Series 215:275-282. DOI: 10.3354/meps215275.

Holmberg J., Norman B., Arzoumanian Z. 2009. Estimating population size, structure, and residency time for whale sharks Rhincodon typus through collaborative photoidentification. Endangered Species Research 7:39-53. DOI: 10.3354/esr00186.

Hsu H-H., Joung S-J., Liao Y-Y., Liu K-M. 2007. Satellite tracking of juvenile whale sharks, Rhincodon typus, in the Northwestern Pacific. Fisheries Research 84:25-

572 Hutchinson GE. 1967. A Treatise on Limnology. New York: Wiley.

573 Jaine FRA., Couturier LIE., Weeks SJ., Townsend KA., Bennett MB., Fiora K., 574 Richardson AJ. 2012. When giants turn up: Sighting trends, environmental 
575 influences and habitat use of the manta ray Manta alfredi at a coral reef. PLoS ONE 576 7:e46170. DOI: 10.1371/journal.pone.0046170.

577 Jonahson M., Harding S. 2007. Occurrence of whale sharks (Rhincodon typus) in 578 Madagascar. Fisheries Research 84:132-135. DOI: 10.1016/j.fishres.2006.11.023.

579 Lalli CM., Parsons TR. 1997. Biological Oceanography - An Introduction. Elsevier. DOI: $580 \quad$ 10.1017/CBO9781107415324.004.

581 Lamont T., Roberts MJ., Barlow RG., Morris T., van den Berg M a. 2010. Circulation 582 patterns in the Delagoa Bight, Mozambique, and the influence of deep ocean 583 eddies. African Journal of Marine Science 32:553-562. DOI: 584 585 586 587 588 589 10.2989/1814232X.2010.538147.

Leeney RH. 2017. Are sawfishes still present in Mozambique? A baseline ecological study. PeerJ 5:e2950. DOI: 10.7717/peerj.2950.

Loose CJ., Dawidowicz P. 1994. Trade-offs in diel vertical migration by zooplankton: The costs of predator avoidance. Ecology 75:2255-2263.

MacLeod C. 2013. An Introduction to Using GIS in Marine Ecology. Glasgow: Pictish Beast Publications.

Malauene BS., Shillington F a., Roberts MJ., Moloney CL. 2014. Cool, elevated chlorophyll-a waters off northern Mozambique. Deep Sea Research Part II: Topical Studies in Oceanography 100:68-78. DOI: 10.1016/j.dsr2.2013.10.017.

Nathan R., Getz WM., Revilla E., Holyoak M., Kadmon R., Saltz D., Smouse PE. 2008. 598 105:19052-19059. DOI: 10.1073/pnas.0800375105.

Norman BM., Holmberg J., Arzoumanian Z., Reynolds S., Wilson RP., Rob D., Pierce SJ., Gleiss AC., de la Parra R., Galvan B., Ramirez-Macias D., Robinson DP., Fox S., Graham R., Rowat D., Potenski M., Levine M., Mckinney JA., Hoffmayer ER., Dove ADM., Hueter RE., Ponzo A., Araujo G., Aca E., David D., Rees R., Duncan A., Rohner CA., Prebble CEM., Hearn AR., Acuna D., Berumen ML., Vazquez A., Green J., Bach S., Schmidt J V., Beatty S., Morgan DL. In press. Undersea constellations: "Citizen scientists" elucidate the global biology of threatened marine mega-vertebrate. BioScience.

Ohlhorst SL. 1982. Diel migration patterns of demersal reef zooplankton. Journal of Experimental Marine Biology and Ecology 60:1-15. DOI: 10.1016/00220981(81)90176-3. 
608 Pierce SJ., Méndez-Jiménez A., Collins K., Rosero-Caicedo M., Monadjem A. 2010. 609 Developing a Code of Conduct for whale shark interactions in Mozambique. Aquatic 610 Conservation: Marine and Freshwater Ecosystems 20:782-788. DOI: $611 \quad$ 10.1002/aqc.1149.

612 Pierce SJ., Norman B. 2016. Rhincodon typus. IUCN Red List of Threatened Species.

613 Plourde S., Runge JA. 1993. Reproduction of the planktonic copepod Calanus 614 finmarchicus in the lower St Lawrence Estuary: Relation to the cycle of 615 phytoplankton production and evidence for a Calanus pump. Marine Ecology 616 Progress Series 102:217-228. DOI: 10.3354/meps102217.

617 R Development Core Team. 2008. R: A language and environment for statistical 618 computing.

619 Ramírez-Macías D., Queiroz N., Pierce SJ., Humphries NE., Sims DW., Brunnschweiler 620 JM. 2017. Oceanic adults, coastal juveniles: tracking the habitat use of whale 621 sharks off the Pacific coast of Mexico. PeerJ 5:e3271. DOI: 10.7717/peerj.3271.

622 Richardson AJ., Schoeman DS. 2004. Climate impact on plankton ecosystems in the 623 Northeast Atlantic. Science 305:1609-1612. DOI: 10.1126/science.1100958.

624 Robinson DP., Jaidah MY., Bach S., Lee K., Jabado RW., Rohner CA., March A., 625 Caprodossi S., Henderson AC., Mair JM., Ormond R., Pierce SJ. 2016. Population 626 627 structure, abundance and movement of whale sharks in the arabian gulf and the gulf of Oman. PLOS ONE 11. DOI: 10.1371/journal.pone.0158593.

Robinson DP., Jaidah MY., Bach SS., Rohner CA., Jabado RW., Ormond R., Pierce SJ. 2017. Some like it hot: repeat migration and residency of whale sharks within an extreme natural environment. PLoS ONE 12(9): e0185360.

Robinson DP., Jaidah MY., Jabado RW., Lee-Brooks K., Nour El-Din NM., Al Malki AA., Elmeer K., McCormick PA., Henderson AC., Pierce SJ., Ormond RFG. 2013. Whale sharks, Rhincodon typus, aggregate around offshore platforms in Qatari waters of the Arabian Gulf to feed on fish spawn. PLOS ONE 8:e58255. DOI: 10.1371/journal.pone.0058255.

Rohner CA., Armstrong AJ., Pierce SJ., Prebble CEM., Cagua EF., Cochran JEM., Berumen ML., Richardson AJ. 2015a. Whale sharks target dense prey patches of sergestid shrimp off Tanzania. Journal of Plankton Research 37:352-362. DOI: 10.1093/plankt/fbv010.

Rohner CA., Couturier LIE., Richardson AJ., Pierce SJ., Prebble CEM., Gibbons MJ., 
641 Nichols PD. 2013a. Diet of whale sharks Rhincodon typus inferred from stomach 642 content and signature fatty acid analyses. Marine Ecology Progress Series 643 493:219-235. DOI: 10.3354/meps10500.

644 Rohner CA., Flam AL., Pierce SJ., Marshall AD. 2017. Steep declines in sightings of 645 manta rays and devilrays (Mobulidae) in southern Mozambique. PeerJ Preprints:1646 32. DOI: https://doi.org/10.7287/peerj.preprints.3051v1.

647 Rohner CA., Pierce SJ., Marshall AD., Weeks SJ., Bennett MB., Richardson AJ. 2013b. 648 Trends in sightings and environmental influences on a coastal aggregation of manta 649 rays and whale sharks. Marine Ecology Progress Series 482:153-168. DOI: 10.3354/meps 10290.

Rohner CA., Richardson AJ., Marshall AD., Weeks SJ., Pierce SJ. 2011. How large is the world's largest fish? Measuring whale sharks Rhincodon typus with laser photogrammetry. Journal of Fish Biology 78:378-385. DOI: 10.1111/j.10958649.2010.02861.x.

Rohner CA., Richardson AJ., Prebble CEM., Marshall AD., Bennett MB., Weeks SJ., Cliff G., Wintner SP., Pierce SJ. 2015b. Laser photogrammetry improves size and demographic estimates for whale sharks. PeerJ 3:e886. DOI: 10.7717/peerj.886.

Rowat D., Brooks KS. 2012. A review of the biology, fisheries and conservation of the whale shark Rhincodon typus. Journal of Fish Biology 80:1019-1056. DOI: 10.1111/j.1095-8649.2012.03252.x.

Rowat D., Brooks K., March A., McCarten C., Jouannet D., Riley L., Jeffreys G., Perri M., Vely M., Pardigon B. 2011. Long-term membership of whale sharks (Rhincodon typus) in coastal aggregations in Seychelles and Djibouti. Marine and Freshwater Research 62:621-627. DOI: 10.1071/MF10135.

Rowat D., Gore M. 2007. Regional scale horizontal and local scale vertical movements of whale sharks in the Indian Ocean off Seychelles. Fisheries Research 84:32-40. DOI: 10.1016/j.fishres.2006.11.009.

Sequeira AMM., Mellin C., Delean S., Meekan MG., Bradshaw CJA. 2013. Spatial and temporal predictions of inter-decadal trends in Indian Ocean whale sharks. Marine Ecology Progress Series 478:185-195. DOI: 10.3354/meps10166.

Sequeira AMM., Mellin C., Floch L., Williams PG., Bradshaw CJA. 2014. Inter-ocean asynchrony in whale shark occurrence patterns. Journal of Experimental Marine Biology and Ecology 450:21-29. DOI: 10.1016/j.jembe.2013.10.019. 
674 Sims DW. 2010. Tracking and analysis techniques for understanding free-ranging shark 675 movements and behaviour. In: Carrier JC, Musick JA, Heithaus MR eds. Sharks 676 and Their Relatives II Biodiversity, Adaptive Physiology, and Conservation. CRC 677 Press, 351. DOI: 10.1201/9781420080483.

678 Sims DW., Southall EJ., Richardson AJ., Reid PC., Metcalfe JD. 2003. Seasonal 679 movements and behaviour of basking sharks from archival tagging: No evidence of 680 winter hibernation. Marine Ecology Progress Series 248:187-196. DOI: $681 \quad 10.3354 /$ meps248187.

682 Sims DW., Witt MJ., Richardson AJ., Southall EJ., Metcalfe JD. 2006. Encounter 683 success of free-ranging marine predator movements across a dynamic prey 684 landscape. Proceedings of the Royal Society B: Biological Sciences 273:1195685 1201. DOI: $10.1098 / \mathrm{rspb} .2005 .3444$.

Sleeman JC., Meekan MG., Wilson SG., Jenner CKS., Jenner MN., Boggs GS., Steinberg CC., Bradshaw CJA. 2007. Biophysical correlates of relative abundances of marine megafauna at Ningaloo Reef, Western Australia. Marine and Freshwater Research 58:608-623. DOI: 10.1071/MF06213.

Sleeman JC., Meekan MG., Wilson SG., Polovina JJ., Stevens JD., Boggs GS., Bradshaw CJA. 2010. To go or not to go with the flow: Environmental influences on whale shark movement patterns. Journal of Experimental Marine Biology and Ecology 390:84-98. DOI: 10.1016/j.jembe.2010.05.009.

Speed CW., Meekan MG., Rowat D., Pierce SJ., Marshall AD., Bradshaw CJA. 2008. Scarring patterns and relative mortality rates of Indian Ocean whale sharks. Journal of Fish Biology 72:1488-1503. DOI: 10.1111/j.1095-8649.2008.01810.x.

Tibiriçá Y., Birtles A., Valentine P., Miller DK. 2011. Diving tourism in Mozambique: An opportunity at risk? Tourism in Marine Environments 7:141-151. DOI: 10.3727/154427311X13195453162732.

701

Tyminski JP., De La Parra-Venegas R., Cano JG., Hueter RE. 2015. Vertical movements and patterns in diving behavior of whale sharks as revealed by pop-up satellite tags in the Eastern Gulf of Mexico. PLOS ONE 10. DOI: 10.1371/journal.pone.0142156.

United Nations Development Programme. 2016. United Nations Human Development 706 Report 2016.

Ware DM. 2005. Bottom-up ecosystem trophic dynamics determine fish production in the northeast Pacific. Science 308:1280-1284. DOI: 10.1126/science.1109049. 
707 Wilson SG., Polovina JJ., Stewart BS., Meekan MG. 2006. Movements of whale sharks 708 (Rhincodon typus) tagged at Ningaloo Reef, Western Australia. Marine Biology 709 148:1157-1166. DOI: 10.1007/s00227-005-0153-8.

710 WWF Eastern African Marine Ecoregion. 2004. Towards a Western Indian Ocean 711 dugong conservation strategy: the status of dugongs in the Western Indian Ocean 712 region and priority conservation actions. Dar es Salaam, Tanzania.

713 Zagaglia CR., Lorenzzetti JA., Stech JL. 2004. Remote sensing data and longline 714 catches of yellowfin tuna (Thunnus albacares) in the equatorial Atlantic. Remote 715 Sensing of Environment 93:267-281. DOI: 10.1016/j.rse.2004.07.015. 
Figure 1

Whale shark and gill net locations

Whale shark and gill net locations from aerial surveys (conducted in 2004-2008 and in 2016, respectively). Density of whale shark sightings along $(A)$ the northern and $(B)$ southern stretch of the southern Mozambique coast and (C) along the northern South Africa coast. The red line shows the flight path of whale shark surveys and a cross indicates gill nets in use.

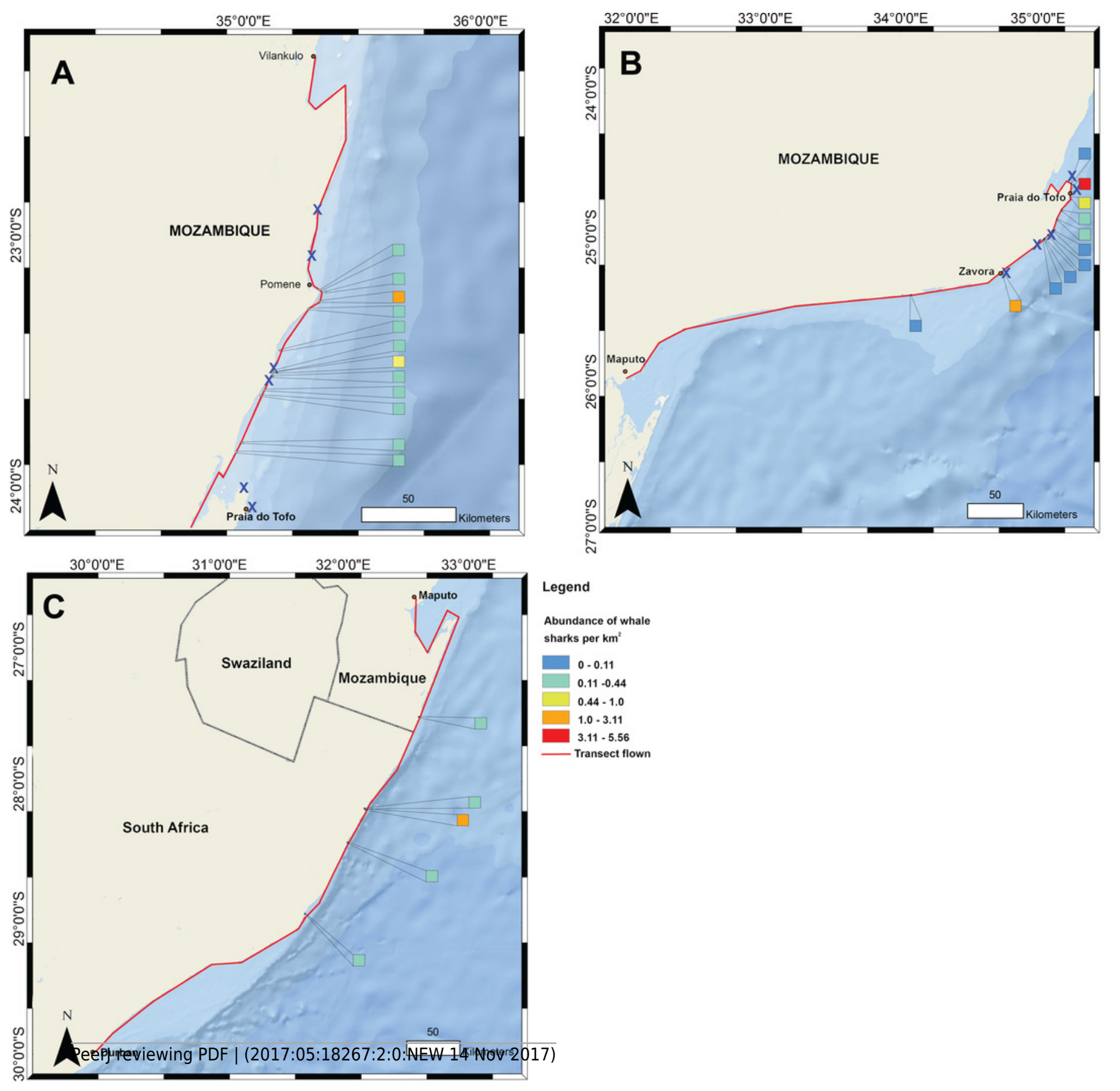




\section{Figure 2}

Whale shark tracks in the southern Mozambique Channel.

Bathymetry maps showing the movements of satellite-tagged sharks. (A) Sharks that included large-scale movement off the continental shelf $(n=8)$. (B) All sharks that remained locally on the continental shelf $(n=7)$. Circle $=$ winter, triangle $=$ spring, square $=$ summer deployments.

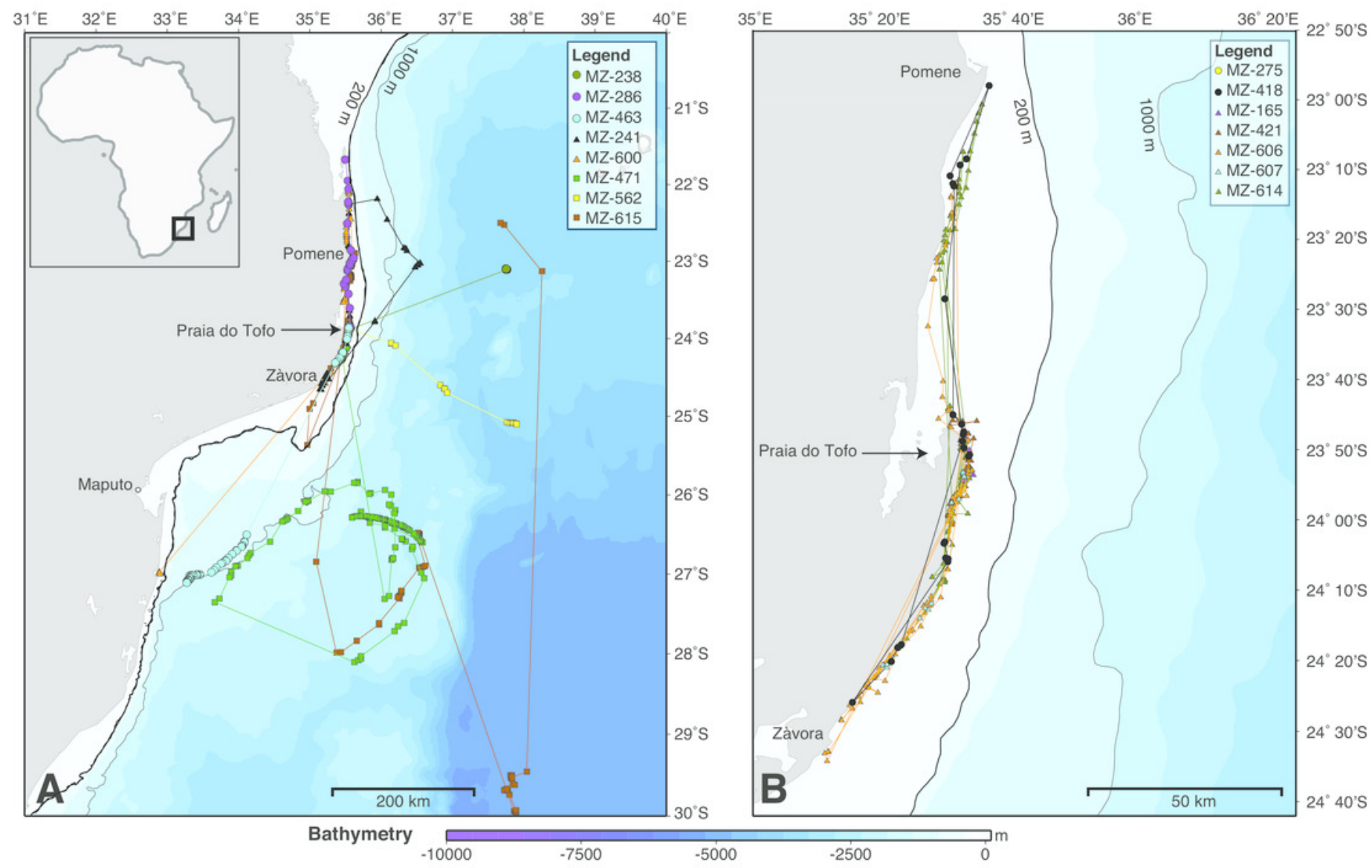


Figure 3

Kernel density maps

Kernel density estimations from all satellite tag locations for $(A)$ tracked whale sharks and $(B)$ random model sharks.
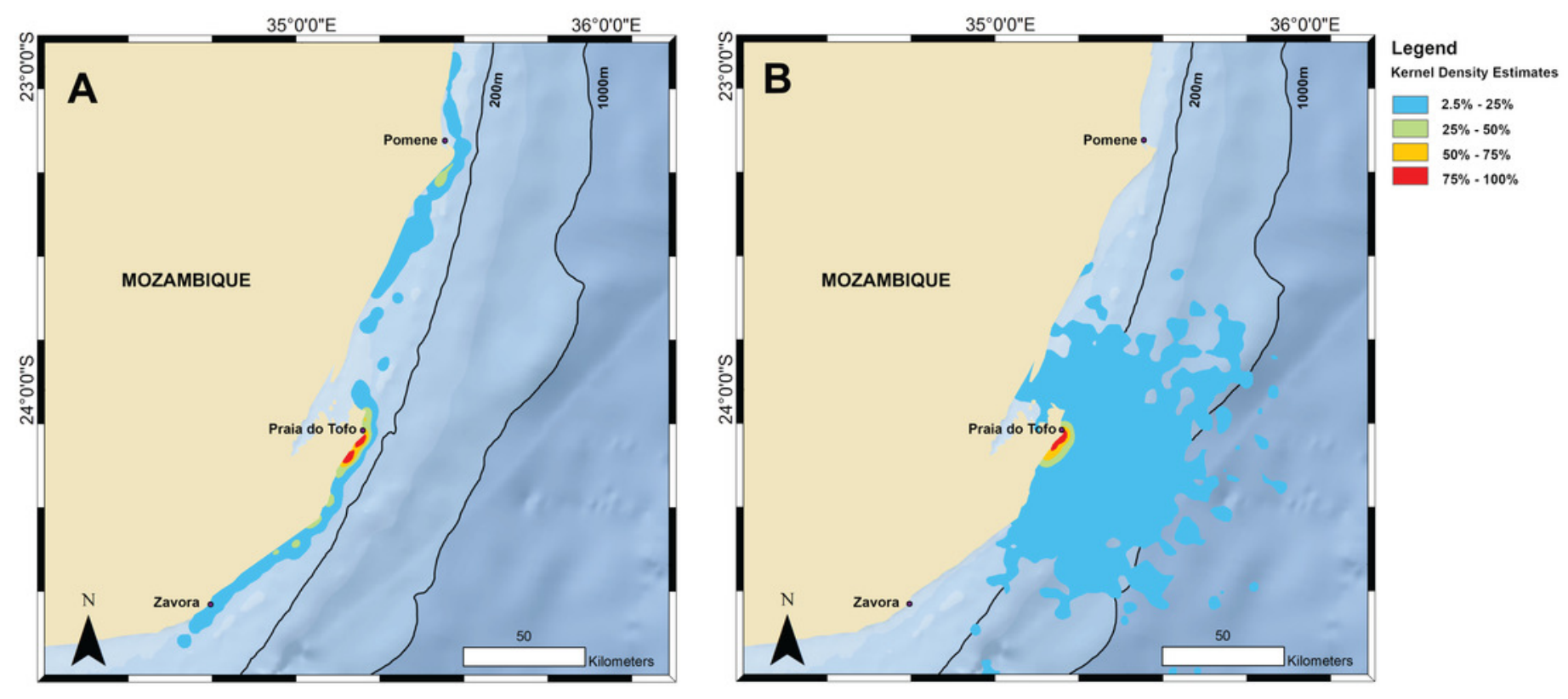
Figure 4

Sea surface temperature preferences.

(A) Number of tag transmissions in each sea surface temperature bin, showing a wide temperature distribution and an affinity for surface temperatures of $22-26^{\circ} \mathrm{C}$. (B) Number of transmissions made by the tags in each month, with mean monthly sea surface temperature plotted for Praia do Tofo (square, $23.85^{\circ} \mathrm{S}, 35.62^{\circ} \mathrm{E}$ ) and $45 \mathrm{~km}$ directly offshore (circle, $\left.23.85^{\circ} \mathrm{S}, 36.00^{\circ} \mathrm{E}\right)$. 
A

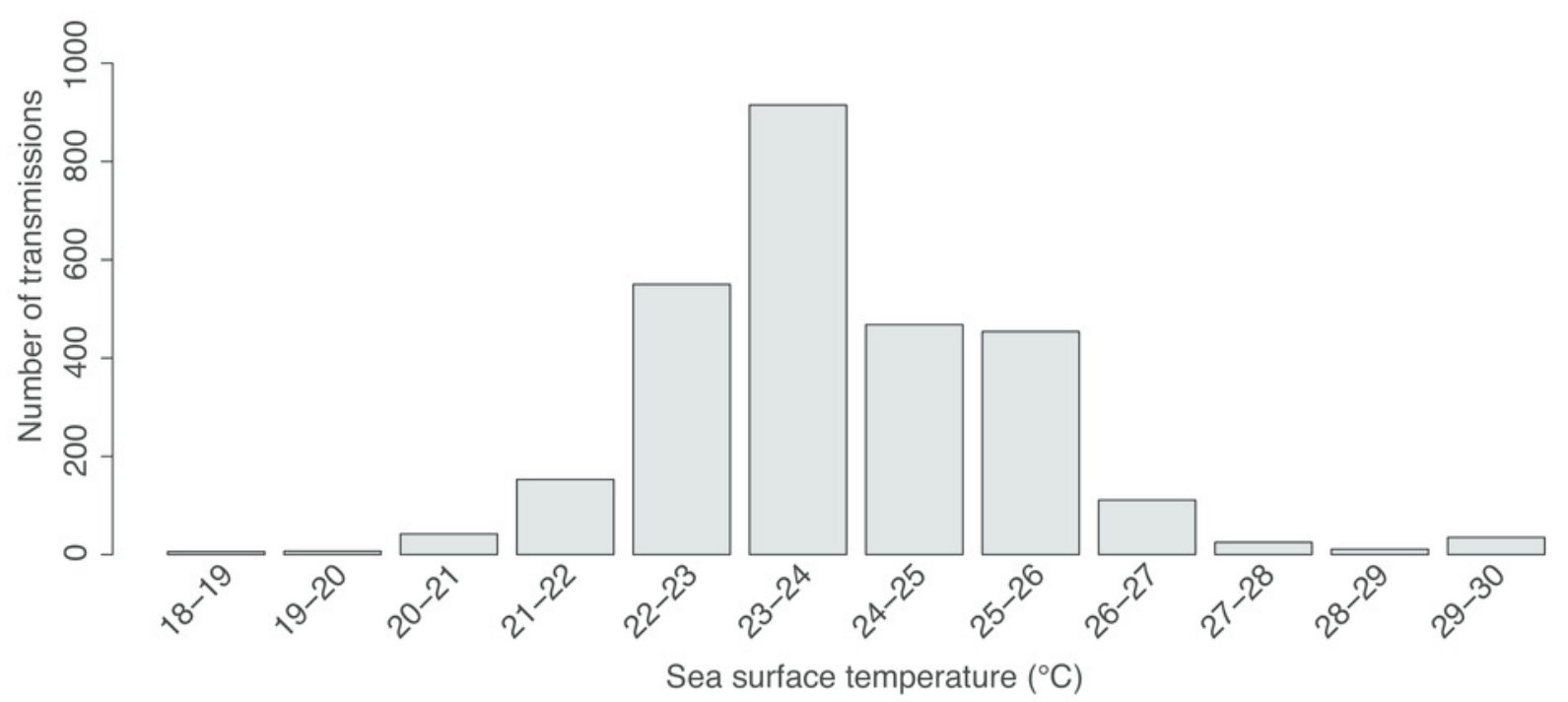

B

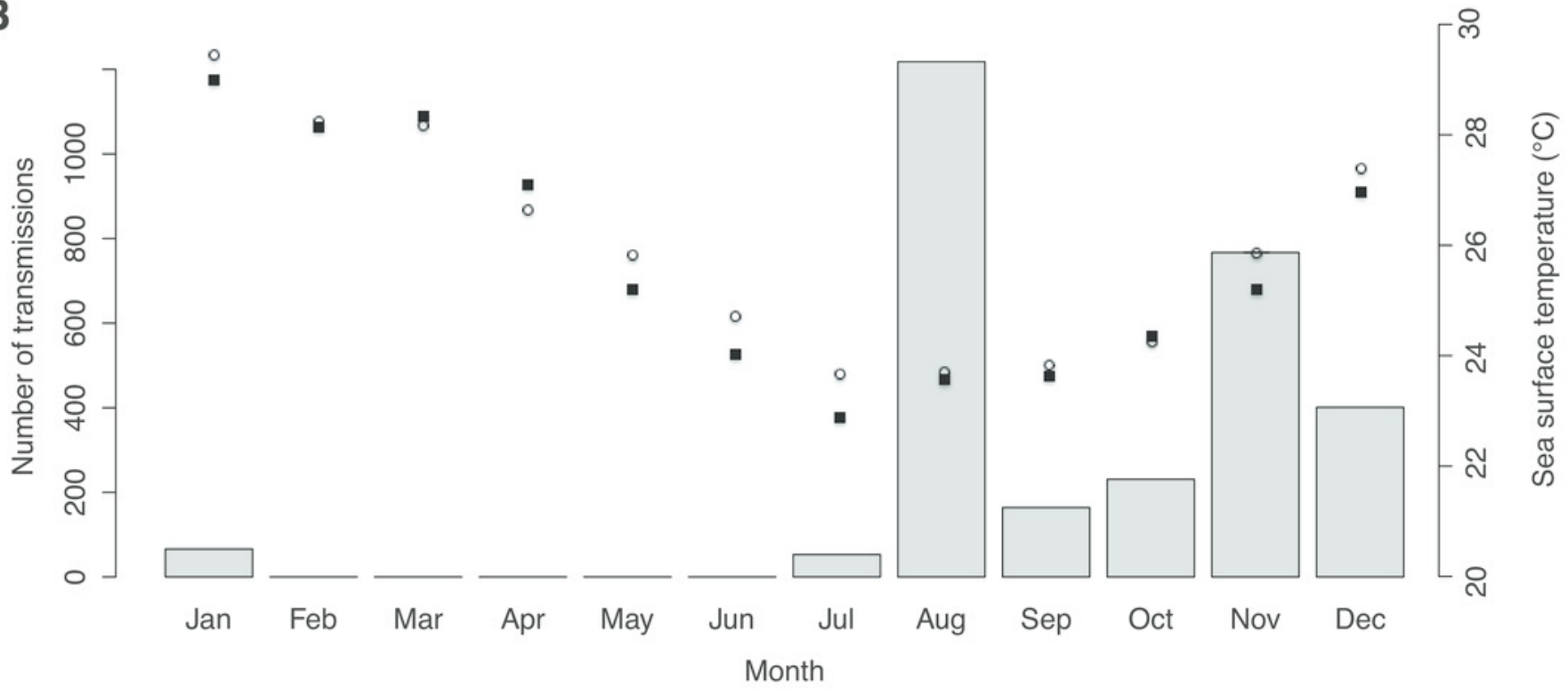




\section{Figure 5}

Real vs. random tracks.

Distributions for all locations of real tracks ("whale shark tracks", white) and for all locations of 100 random tracks per real shark ("modelled shark tracks", grey) of satellite-derived (A) sea surface temperature (SST) and (B) chlorophyll-a concentration (Chl-a). Nine-month mean images of (C) SST and (D) Chl-a showing their respective mean regional distributions for the study period.
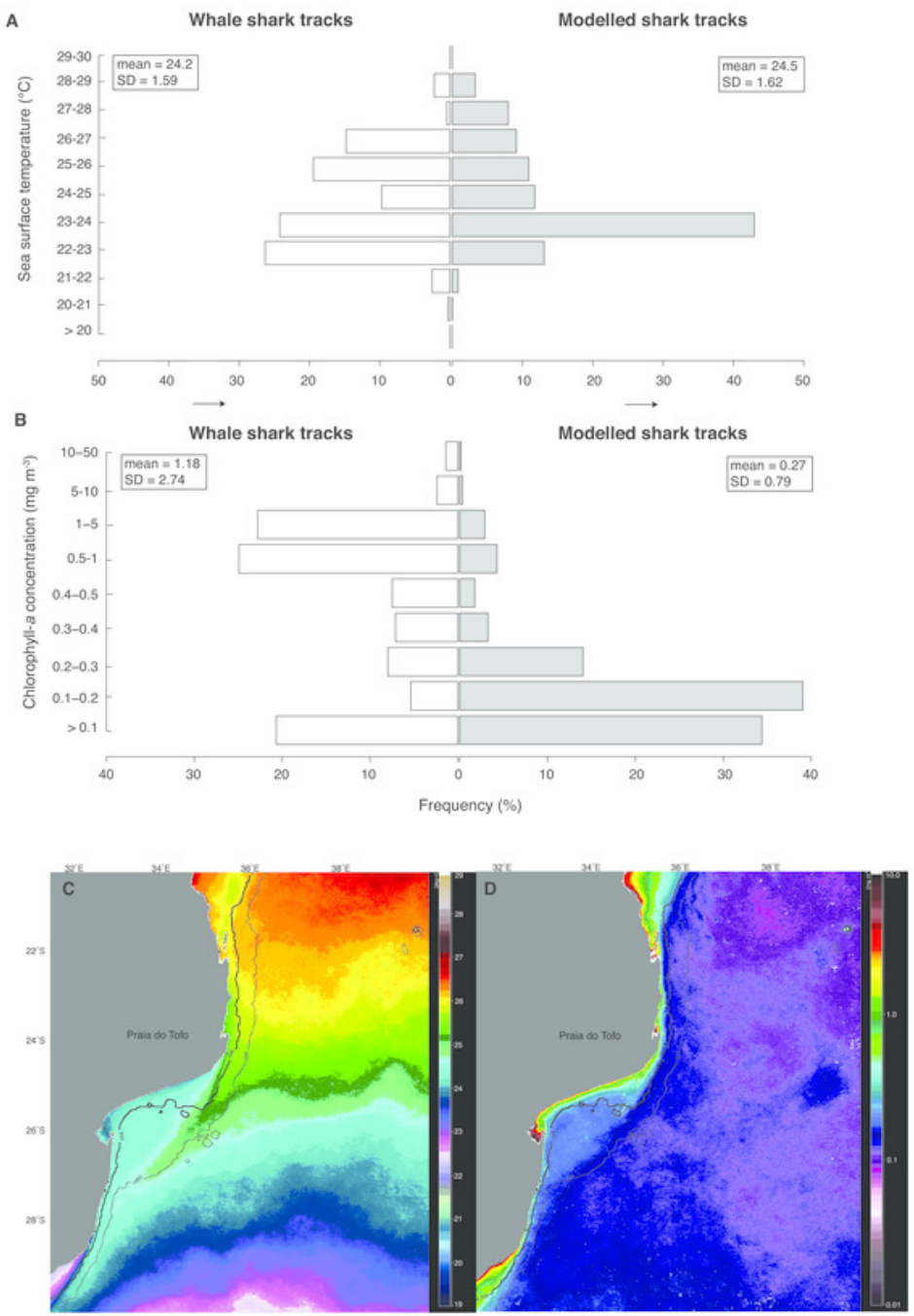
Figure 6

Sea surface vs. vertically-integrated temperatures.

Proportion of time spent in each temperature bin for sea surface temperature of all locations ("Sea surface temperature") and for tag-recorded, time-integrated temperature ("Tag temperature data") for locations (A) on the shelf and (B) off the shelf for all tags.

A

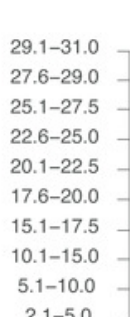

$2.1-5.0$

B

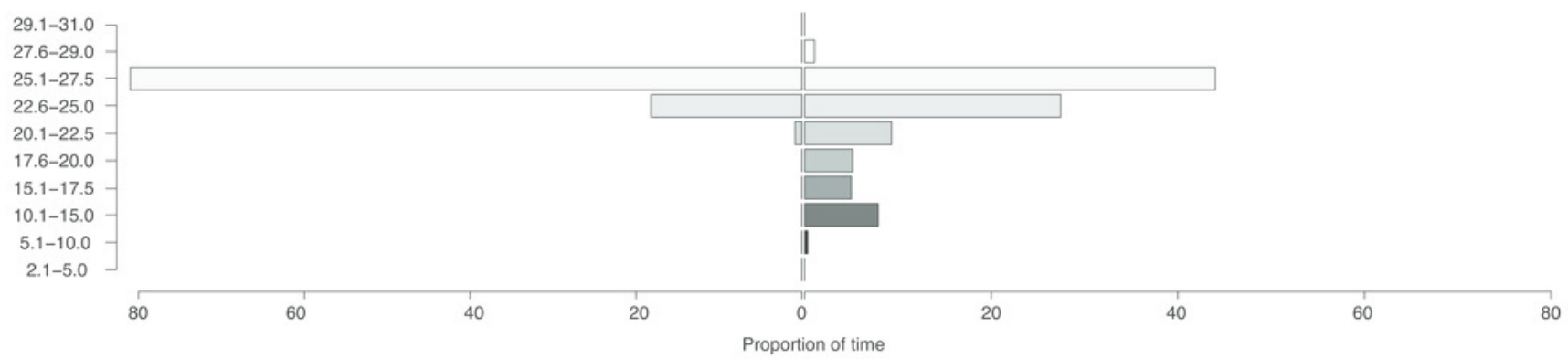




\section{Table $\mathbf{1}$ (on next page)}

Track details of 15 whale sharks equipped with SPOT5 tags

Track details of 15 whale sharks equipped with SPOT5 tags, with track number, shark ID on the Wildbook for Whale Sharks global database, sex, total length (TL), track start and end date and track duration. Track distance is measured as the sum of the straight-line distances between two adjacent locations, only including locations of ARGOS class (LC) 3, 2 and 1. 
Table 1. Track details of 15 whale sharks equipped with SPOT5 tags, with track number, shark ID on the Wildbook for Whale Sharks global database, sex, total length (TL), track start and end date and track duration. Track distance is measured as the sum of the straight-line distances between two adjacent locations, only including locations of ARGOS

class (LC) 3, 2 and 1.

\begin{tabular}{|c|c|c|c|c|c|c|c|c|c|c|c|}
\hline \# & ID & Sex & $\begin{array}{l}\mathrm{TL} \\
(\mathrm{cm})\end{array}$ & Start date & End date & Days & $\begin{array}{l}\text { Track } \\
\text { distance } \\
(\mathrm{km})\end{array}$ & $\begin{array}{l}\text { Speed (km } \\
\text { day-1) }\end{array}$ & $\begin{array}{l}\text { No. of fixes } \\
\left(\text { Pos. day }{ }^{-1}\right)\end{array}$ & $\begin{array}{l}\text { Number of } \\
\text { fixes (LC } \\
3,2,1 \text { day- } \\
\text { 1) }\end{array}$ & $\begin{array}{l}\text { Days with } \\
\text { locations (\% of } \\
\text { total tracking } \\
\text { days) }\end{array}$ \\
\hline 1 & $M Z-421$ & $M$ & 560 & 11-Nov-10 & 14-Nov-10 & 4 & 66.6 & 16.7 & 8.7 & 6.7 & $4(100 \%)$ \\
\hline 2 & $M Z-562$ & $M$ & 540 & 02-Feb-11 & 05-Feb-11 & 4 & 280.3 & 70.1 & 9.7 & 4.7 & $3(75 \%)$ \\
\hline 3 & MZ-286 & $\mathrm{F}$ & 550 & 19-Jul-11 & 28-Jul-11 & 10 & 261.5 & 26.1 & 6.9 & 4.2 & $8(80 \%)$ \\
\hline 4 & MZ-275 & $M$ & 745 & 22-Jul-11 & 25-Jul-11 & 4 & 10.4 & 2.6 & 6.0 & 2.3 & $2(50 \%)$ \\
\hline 5 & $M Z-418$ & $M$ & 700 & 09-Aug-11 & 18-Aug-11 & 10 & 325.5 & 32.6 & 7.1 & 2.6 & $10(100 \%)$ \\
\hline 6 & $M Z-238$ & $M$ & 600 & 09-Aug-11 & 24-Aug-11 & 16 & 412.7 & 25.8 & 5.4 & 2.0 & 10 (63\%) \\
\hline 7 & MZ-241 & $M$ & 630 & 10-Aug-11 & 03-Sep-11 & 25 & 814.6 & 32.6 & 5.4 & 2.9 & $23(92 \%)$ \\
\hline 8 & $M Z-463$ & $M$ & 635 & 11-Aug-11 & 21-Aug-11 & 11 & 457.1 & 41.6 & 8.4 & 5.6 & $6(55 \%)$ \\
\hline 9 & MZ-606 & $M$ & 550 & 26-Aug-11 & 20-Sep-11 & 26 & 668.0 & 25.7 & 7.8 & 3.8 & $21(81 \%)$ \\
\hline 10 & MZ-607 & $M$ & 865 & 11-Aug-11 & 05-Oct-11 & 56 & 204.5 & 3.7 & 1.0 & 0.3 & 8 (14\%) \\
\hline 11 & $M Z-600$ & $M$ & 600 & 23-Jul-11 & 18-Oct-11 & 88 & 2446.8 & 27.8 & 5.1 & 3.2 & $38(43 \%)$ \\
\hline 12 & MZ-614 & $M$ & 600 & $12-O c t-11$ & 08-Nov-11 & 28 & 677.0 & 24.2 & 8.6 & 3.6 & $24(86 \%)$ \\
\hline 13 & MZ-615 & $F$ & 650 & 26-Oct-11 & 17-Jan-12 & 84 & 2736.7 & 32.6 & 3.7 & 1.6 & $38(45)$ \\
\hline 14 & MZ-165 & $M$ & 670 & 25-Nov-11 & 26-Nov-11 & 2 & 23.9 & 11.9 & 12.0 & 6.0 & $2(100 \%)$ \\
\hline 15 & MZ-471 & $\mathrm{M}$ & 820 & 28-Nov-11 & 01-Jan-12 & 35 & 1687.0 & 48.2 & 6.0 & 3.7 & $23(66 \%)$ \\
\hline \multicolumn{2}{|c|}{ Maximum } & & 865 & & & 88 & 2737 & 70.1 & 12.0 & 6.7 & $100 \%$ \\
\hline \multicolumn{2}{|c|}{ Minimum } & & 540 & & & 2 & 10 & 2.6 & 1.0 & 0.3 & $14 \%$ \\
\hline \multicolumn{2}{|c|}{ Mean } & & 648 & & & 26.9 & 738 & 28.1 & 5.0 & 2.6 & $55 \%$ \\
\hline
\end{tabular}




\section{Table 2 (on next page)}

Published whale shark tagging study information

Published whale shark tagging study information, with tag type, $\mathrm{N}=$ number of tracked sharks, $M=$ males, $F=$ females, mean total length and range in brackets $(\mathrm{cm})$, mean $( \pm S D)$ total distance travelled, tag attachment duration and mean ( \pm SD) daily speed. Failed tags are not included in the analysis. * indicates straight-line distances from tagging to pop-up location. ${ }^{* *} \mathrm{~A}$ record of a $>13,000 \mathrm{~km}$ track from this paper is now broadly considered to be from a floating tag (Andrzejaczek et al., 2016) . 
Table 2. Published whale shark tagging study information, with tag type, $N=$ number of tracked sharks, $M=$ males, $F=$ females, mean total length and range in brackets $(\mathrm{cm})$, mean $( \pm \mathrm{SD})$ total distance travelled, tag attachment duration and mean $( \pm$ SD) daily speed. Failed tags are not included in the analysis. " indicates straight-line distances from tagging to pop-up location. ${ }^{* *} A$ record of a >13, $000 \mathrm{~km}$ track from this paper is now broadly considered to be from a floating tag (Andrzejaczek et al., 2016).

\begin{tabular}{|c|c|c|c|c|c|c|c|}
\hline Location & Tag type & $N(M, F)$ & Total length $(\mathrm{cm})$ & Distance (km) & Duration (days) & Speed $\left(k^{\prime} d^{-1}\right)$ & Reference \\
\hline Mozambique & Real-time & $15(12,3)$ & $648(540-865)$ & $738( \pm 861.7)$ & $26( \pm 28.0)$ & $29( \pm 30.7)$ & This study \\
\hline Qatar & Real-time & $28(17,11)$ & $704(500-900)$ & $378( \pm 546.3)$ & $69( \pm 60.7)$ & $7( \pm 13.5)$ & Robinson et al. 2017 \\
\hline Ecuador & Mix & $26(0,26)$ & $1047(400-1,310)$ & $2,273( \pm 1,933.6)$ & $62( \pm 50.6)$ & $41( \pm 25.5)$ & Hearn et al., 2016 \\
\hline Saudi Arabia & Archival & $47(14,16)$ & $391(300-700)$ & $502( \pm 613.4)$ & $146( \pm 80.3)$ & $4( \pm 4.9)$ & Berumen et al., 2014 \\
\hline Mexico & Archival & $28(10,18)$ & $738(500-900)$ & $699( \pm 1,322.8)$ & $68.4( \pm 54.5)$ & $9( \pm 11.0)$ & Hueter, Tyminski \& de la Parra, 2013 \\
\hline Mozambique & Archival & $2(1,1)$ & $725(650-800)$ & $607( \pm 838.6)^{*}$ & $47( \pm 56.6)$ & $8( \pm 8.3)$ & Brunnschweiler et al., 2009 \\
\hline Seychelles & Real-time & $3(1,-)$ & $617(500-700)$ & $1,769( \pm 1,471.2)$ & $42( \pm 20.8)$ & $43( \pm 70.6)$ & Rowat \& Gore, 2007 \\
\hline Taiwan & Real-time & $3(3,0)$ & $423(400-450)$ & $4,250( \pm 1,458.1)$ & $143( \pm 56.1)$ & $30( \pm 26.0)$ & Hsu et al., 2007 \\
\hline Australia & Archival & $10(1,7)$ & $715(470-1,100)$ & $581( \pm 544.8)^{*}$ & $92( \pm 88.9)$ & $6( \pm 6.1)$ & Wilson et al., 2006 \\
\hline SE Asia & Real-time & $6(-,-)$ & $567(300-700)$ & $890( \pm 1,284.1)$ & $35( \pm 48.9)$ & $25( \pm 26.2)$ & Eckert et al., 2002 \\
\hline Mexico & Real-time & $14(-, 7)$ & $643(300-1,800)$ & $1,812( \pm 3,749.4)$ & $149( \pm 334.6)$ & $12( \pm 11.2)$ & Eckert \& Stewart, $2001^{* *}$ \\
\hline
\end{tabular}

